NBER WORKING PAPER SERIES

\title{
REQUIESCAT IN PACE? THE CONSEQUENCES OF HIGH PRICED FUNERALS IN SOUTH AFRICA
}

\author{
Anne Case \\ Alicia Menendez \\ Working Paper 14998 \\ http://www.nber.org/papers/w14998
}

\author{
NATIONAL BUREAU OF ECONOMIC RESEARCH \\ 1050 Massachusetts Avenue \\ Cambridge, MA 02138
}

May 2009

We have benefited from the help of the Agincourt Health and Population Unit under the leadership of Stephen Tollman and Kathy Kahn. We thank Mark Collinson and Martin Wittenberg for help in drawing a sample, Merton Dagut for survey management, Alice Muehlhof for expert data assistance, Karla Hoff for many useful conversations, Esther Duflo for helpful comments on an earlier draft, and the NIH for financial support under grants from the National Institute on Aging R01 AG20275-01, P01 AG05842-14 and P30 AG024361. The views expressed herein are those of the author(s) and do not necessarily reflect the views of the National Bureau of Economic Research.

NBER working papers are circulated for discussion and comment purposes. They have not been peerreviewed or been subject to the review by the NBER Board of Directors that accompanies official NBER publications.

(C) 2009 by Anne Case and Alicia Menendez. All rights reserved. Short sections of text, not to exceed two paragraphs, may be quoted without explicit permission provided that full credit, including $\odot$ notice, is given to the source. 
Requiescat in Pace? The Consequences of High Priced Funerals in South Africa Anne Case and Alicia Menendez

NBER Working Paper No. 14998

May 2009

JEL No. D12,O12

\title{
ABSTRACT
}

We examine the costs associated with funerals and the effects of funeral spending on household functioning, using data collected in the Agincourt Demographic Surveillance Site in South Africa. We find that large outlays of money at the time of the funeral leave households vulnerable to future hardship. Householdsthat buried a member report lower spending per person, poorer adult affect, and lower rates of school enrollment for children than do other households. We present evidence consistent with the financial burden associated with a funeral having direct, adverse effects on households.

\author{
Anne Case \\ 367 Wallace Hall \\ Princeton University \\ Princeton, NJ 08544 \\ and NBER \\ accase@princeton.edu \\ Alicia Menendez \\ Harris School of Public Policy \\ University of Chicago \\ Chicago, IL 60637 \\ menendez@uchicago.edu
}




\section{Introduction}

Funerals can serve several purposes, including honoring the dead, comforting those who grieve, and knitting social fabric for extended families and communities. In Southern Africa, funerals are generally considered an individual's most important rite of passage. As a result, they tend to be more elaborate and expensive than weddings, graduations or naming ceremonies for children. Households may spend the equivalent of a year's income for an adult's funeral, borrowing from money lenders if need be to have a funeral that befits the status of the household and of the person who died (Case et al. 2008).

Social norms surrounding funerals were set at a time when people died largely in early childhood or in old age. Neither type of death would be apt to put financial strain on the household: young children's funerals are simple, and older person's funerals are largely protected by funeral insurance. The AIDS crisis has changed the mortality patterns observed in Southern Africa, with the greatest increase in mortality rates found for adults aged 20 to 34 years old (Kahn et al. 2007a). This increase in mortality in middle age can lead to economic hardship for households that experience a death, if those who die do not have burial policies and if norms of what constitutes an appropriate funeral do not change to reflect the change in mortality patterns.

In this paper, we use data we collected on 2922 individuals in 473 households in the Agincourt Demographic Surveillance Site in South Africa in 2004 to examine funeral spending, and the impact of the death and funeral spending on household functioning. We find that, on average, funeral expenses total 3400 Rand when an adult dies-equivalent to 40 percent of average annual total household expenditure. We find households that experienced a death in the past five years have significantly lower expenditure per person than do other households. Adults 
in households that experienced a death report significantly more symptoms of depression and anxiety, and significantly more problems in their households. Children in households that experienced a death in the past five years are significantly less likely to be enrolled in school than are other children their age. Many of these difficulties can be explained by the amount of money that the household spent on the funeral.

Section 2 introduces the Agincourt Demographic Surveillance Site and presents summary statistics on the sample drawn for analysis. Section 3 examines funeral costs, and reports contributions made toward funeral expenses by household members and others. Section 4 looks at the association between death in the household in the past 5 years and outcomes for members on a variety of dimensions. Section 5 discusses alternative explanations for our findings, and Section 6 concludes.

\section{The Agincourt Demographic Surveillance Site}

The Agincourt Health and Population Unit (AHPU) is an educational and research unit located within the School of Public Health at the University of the Witwatersrand, South Africa. Since 1992, AHPU has been collecting information on birth, death and migration for all individuals identified as members of the approximately 11,700 households under surveillance in a rural subdistrict in (what is now) Mpumalanga Province, South Africa. ${ }^{1}$ The area is home to South Africans and Mozambicans, the latter group settling here legally during the civil war in Mozambique. Most Mozambicans here have permanent residency status which, according to the South African Constitutional Court, allows them access to government transfers. However, it is

\footnotetext{
${ }^{1}$ For more information on the Agincourt Unit, see http://web.wits.ac.za/Academic/Health/PublicHealth/Agincourt/
} 
more difficult for Mozambicans to access government grants, largely because they lack the documents necessary to do so (Case and Menendez 2007).

\section{Sample design}

In January 2004, using this census information, we drew a stratified random sample of 475 households, with stratification on both citizenship (South African versus Mozambican) and on whether the household had lost a member to death in the period from June 1, 2002 to May 31, 2003. We chose this window in order to reach households soon enough after the death that memories of funeral spending would still be fresh, but not so soon that we would offend grieving members. Our sample was drawn in such a way that refusals could be replaced by a household in the same (nationality-death status) stratum. Our sample design and the actual number of households interviewed in each stratum is shown in Box 1.

\section{Box 1. Sample design for Agincourt field work}

\begin{tabular}{|l|c|c|c|}
\hline & $\begin{array}{c}\text { Number of } \\
\text { households }\end{array}$ & $\begin{array}{c}\text { South African } \\
\text { households }\end{array}$ & $\begin{array}{c}\text { Mozambican } \\
\text { households }\end{array}$ \\
\hline $\begin{array}{l}\text { No death in } \\
\text { household }\end{array}$ & Design & 190 & 127 \\
\cline { 2 - 4 } & Actual & 187 & 127 \\
\hline $\begin{array}{l}\text { Death in } \\
\text { household }\end{array}$ & Design & 95 & 63 \\
\cline { 2 - 4 } & Actual & 96 & 63 \\
\hline
\end{tabular}


The sample was designed to be 60 percent South African, and 40 percent Mozambican. In execution, slightly fewer South African households without a death were interviewed (187 instead of 190), and one extra South African household with a death was interviewed (96 instead of 95).

These discrepancies were the result of confusion over which households were considered to have a 'complete' interview in cases where the head of household refused to be interviewed. The survey is composed of a household module, to be completed by a knowledgeable household member; an adult module, to be completed by each member aged 18 or older; and a child module, to be completed for each child aged 12 or younger. Some adult household members were migrants who were not in the field site to be interviewed (although the field team made a great effort to make appointments with the household to return at month-end, or at Easter, to interview returning migrants). In addition, some adult members refused to be interviewed. We decided that if the household module was completed, and at least one adult was interviewed, the household had a 'complete' interview.

In the South African-Death Stratum, an extra household was interviewed because the household head came home for Easter, after the rest of the household had been interviewed, and refused to participate. The field team then interviewed a replacement household, but need not have: we had made a decision that if the head refused to participate, but did not stop other members from doing so, then that household's information would be used. However, if a returning head refused to let any members participate (even if they had already been interviewed), we did not use that household in our analysis. 


\section{Data collected}

Households were interviewed between January and July 2004. A knowledgeable household member was asked to provide information about all other members, including their ages, educational attainment, incomes from a variety of sources and, for younger members, whether they were currently enrolled in school. In addition, this person was asked about household assets and household spending on various types of food, phones, fuel, rent, rates, children's schooling, and hire purchase payments. We included a battery of questions on death in the household module. We began by asking about all deaths in the last five years, and went on to ask a set of questions about the funeral of the person who had died most recently.

Every adult in the household was interviewed separately, and was asked about personal expenses (such as their clothing and transport) and about their sources of income. We also asked each about his or her health, mental health, and problems observed in the household.

Summary statistics for the households are presented in Table 1. On average households in the sample have just over 6 members. Mozambican households are significantly larger than South African households, with fully one additional member — generally a child under the age of 18 . South African households are more affluent than their Mozambican counterparts, with expenditure per member on food and other household goods twice as high in South African households, and with a significantly greater number of assets reported. On average, total monthly household spending is approximately equal in value to that of the state old-age pension at this time (which was R740), underscoring the fact that the region is poor. 
Mozambicans report a greater number of deaths of children age five or younger in the last 5 years, but equal numbers of deaths of members aged 5 to 17 , and deaths of adult members (18 and above).

Summary statistics for the most recent death in the household are presented in Table 2, where results are presented for all such deaths, and separately for deaths of adult members (18 and older). Mozambicans are significantly younger on average at death, and significantly less likely to be of pension age (60 years old for women, 65 for men). They are also reported to have completed fewer years of schooling —although educational attainment among the deceased is very low in general, with fewer than 3 years reported for South Africans also. For adult deaths, approximately two-thirds of households report that the most recently deceased's member made an important financial contribution to the household while they were healthy.

Seventy-five percent of households reporting a death came from the strata targeted for a recent death. (We also use information on a death in the past five year if that death fell before or after the window June 1, 2002 to May 31, 2003.) We turn now to the funerals of the most recent death in each household.

\section{Funeral expenses}

For the most recent funeral in the past five years, we asked whether the household spent money for a coffin, meat, groceries, additional cemetery costs, burial and mourning clothing, flowers, transport for mourners, food for a pre-funeral prayer service, and other expenses. ${ }^{2}$ If the respondent reported spending on these categories, we asked the Rand amount for this item.

\footnotetext{
${ }^{2}$ In four cases, no information about the funeral was provided by the knowledgeable household member. In two of these, the funeral was held elsewhere and the respondent did not know what was spent. In two other cases, the respondent was not willing to answer these questions.
} 
Results of these reports are presented in Table 3. The largest outlays are for a coffin, meat for the meal following the funeral, and groceries both for the meal and to feed mourners who come to pay respects (some of whom stay with the mourning household for several days). Sixty-five percent of households report purchasing a coffin and, conditional upon this purchase, report spending 2200 Rand. The vast majority ( 85 percent) report buying meat, and among those who purchased meat, 1100 Rand were spent. Three quarters bought groceries, and those who did spent 700 Rand. The average funeral expenses totaled 2900 Rand, with the relatively wealthier South Africans spending 3700 Rand on average and Mozambicans, 1600 Rand. These totals are presented for all funerals in which any spending was reported. If we restrict the sample to a (possibly more reliable) sample of respondents who remember what was spent on meat, funeral spending totaled 3195 Rand on average.

Significantly less is spent on the funerals of small children. Figure 1 presents total spending on funerals by the age of the deceased. It is clear that, for those younger than age 6 , funerals are much more modest. On average, for the funerals of children aged 0 to 5, 682 Rand were spent. For the funerals of household members older than age 5, on average 3415 Rand were spent. As seen in Figure 2, when we restrict the sample to those who were older than age 5 at their death, there is no relationship between age and funeral spending. ${ }^{3}$ This is true even if large outliers (e.g., two funerals where more than 18000 Rand are reported) are removed from the sample. In what follows, we will use the fact that the funerals for household members ages 6 to 17 are as expensive as funerals for adult members (many of whom had been contributing to household income before their deaths) to argue that it is the death of a member greater than age 5,

\footnotetext{
${ }^{3}$ It is interesting to contrast this with the age-funeral spending profile found among the Zulus, where funeral spending increases with age through age 70 (Case et al. 2008).
} 
or spending on funerals for members greater than age 5 , that is responsible for the hardships that households report after the death of a household member.

Table 4 presents information on who paid for the funeral in the Demographic Surveillance Site. In 81 percent of funerals, household members contributed money and, when they did, on average they contributed almost 2500 Rand. This includes any money that the household received from a burial society or funeral policy for the deceased. Extended family, not in the household, is reported to contribute to 73 percent of all funerals. They contribute a smaller but still substantial sum (1358 Rand on average). The community is reported to contribute in 72 percent of all funerals, and the church in more than half of all funerals, although in both cases substantially less is contributed. Employers contribute to only one in ten funerals, but when they do contribute the amount is substantial (2900 Rand on average). The knowledgeable household member, reporting on the funeral, can remember 3200 Rand of contributions on average, which is close to what was reported on funeral spending (2900 Rand). This adding up need not have happened - questions on what was spent are asked in a separate section from questions on who contributed what - so this provides a check on the quality of the data.

Mechanisms have evolved in South Africa to help individuals save for funerals. These include membership in a burial society, or the purchase of a funeral policy with a funeral parlor or an insurance company. Money paid into a funeral policy can only be drawn upon at death. For approximately 20 to 30 Rand per month (more, if one is insuring additional household members), individuals are guaranteed that some expenses incurred for their funerals will be paid for by the insurer. 
Table 5 presents information on whether the deceased was covered by a burial society or funeral policy and, if so, whether that fund paid money or contributed a coffin, food or transport for the funeral. In a third of all cases, the deceased was covered by a funeral policy or burial society. In a quarter of all deaths, the policy paid money (4750 Rand on average). In 20 percent of cases, the policy contributed a coffin—which would have saved the household approximately 2200 Rand in funeral costs on average.

Ownership of a funeral policy is highly correlated with being of pension age. Each month, after receiving their pension, pensioners can pay into their burial account at the pension pay point. (Funeral parlors and insurance companies are the only private firms allowed to conduct business inside pension pay points, which are generally surrounded by a fence or barrier of some sort.) Seventy percent of pension-aged people who died had a funeral policy, in contrast to 27 percent of those not yet of pension age. Why would younger adults not belong to a burial society? We can only speculate, but one possibility, suggested to us by Karla Hoff, "is the same reason that Duflo et al. (2008) find that farmers aren't keen on buying fertilizer when they need it (at the beginning of the season) but are very responsive to the option to buy fertilizer immediately after their harvest. It might be that people don't like to plan, but if they have money in hand, and a seller is strategically positioned when they receive cash, then they will buy what they know they will need later on." (Karla Hoff, personal correspondence.) A non-competing hypothesis is that planning for one's own death is painful, and more so for the young than for the old.

In what follows, we will focus primarily on the number of deaths and the ages of those who died in the household in the past five years. We will not use information on whether a burial policy paid out, in order to sidestep the issue of whether people who have burial policies know 
how to plan, which may then be a marker that their households are better organized. We turn to the consequences of deaths in the household in the next section.

\section{Household and individual outcomes}

Our identification strategy in quantifying the impact of death and funeral expenses is to assume, by nationality, that households that had experienced a death would be similar in measures of wellbeing to those that did not, if the death had not occurred. We will return in Section 5 to discuss alternative explanations for our findings.

Expenditure per member in 2004

A knowledgeable household member reported expenditures on all household goods, the sum of which we use to construct a marker of current household economic status. Table 6 presents results from OLS regressions in which we regress the log of monthly expenditure per member in 2004 on deaths in the household in the past five years, together with other controls, in order to characterize the impact of the death and funeral. ${ }^{4}$

Column 1 controls separately for the number of deaths of members aged 18 and older, aged 6 to 17, and aged 0 to 5 years old. All regressions include a control for whether the head of household was Mozambican. Consistent with the information presented in Table 1, expenditure per member is approximately twice as high in South African households than in Mozambican households.

\footnotetext{
${ }^{4}$ All regressions include an index for the number of spending categories for which the knowledgeable household member knew something was spent, but does did not know the amount.
} 
We find spending in households that lost an adult in the past five years is approximately 20 percent lower than in households that did not. The point-estimate on the number of deaths of members aged 6 to 17, although imprecisely estimated, also suggests approximately 20 percent lower spending in households who lost members in that age range. An F-test does not reject that the impact of an adult death and that of a member aged 6 to 17 are the same. Spending on the death of a child aged 0 to 5 appears to be orthogonal to current log expenditure per member: the point estimate is small $(-0.02)$ and not significantly different from zero.

In order to present some interaction terms in a parsimonious way, we combine the number of deaths of members ages 6 to 17 and those ages 18 and older, and present results in column 2 . As in column 1, each death in this age group is associated with a 20 percent reduction in household spending per person. Perhaps because only 8 percent of households had multiple deaths in this period, results are very similar if we use an indicator for any deaths of members aged 6 or above (column 3 of Table 6). We continue to find expenditure per member in households with a death is approximately 20 percent lower. We find no difference between deaths of members ages 6 to pension age and those above pension age, which can also be seen in column 3 of Table 6: an indicator that the deceased was of pension age has no significant association with log expenditure per member.

The inclusion of a control that the deceased's income was 'financially important when healthy,' in column 4, reduces the coefficient on the number of deaths aged 6 or above, from 22 to 16 percent. The coefficient on number of death is still negatively and significantly associated with current household spending, while the indicator that the deceased's income was financially important is not. 
In both South African and Mozambican households, death of a member is associated with a 20 percent reduction in spending per person. Column 5 includes an interaction term between the number of deaths of members above the age of five with an indicator that the household was Mozambican. The coefficient on this interaction term is small and insignificantly different from zero.

We also tested whether the impact of a more recent death was larger than that of a death that occurred more than two years ago, to see whether households appear to rebound after a funeral. The regression in column 6 includes an indicator that the most recent death was in 2002, 2003, or 2004 (as opposed to 1999, 2000, or 2001). The coefficient is small, insignificant and of a counterintuitive sign.

The large sums of money spent on funerals must come from somewhere. Results in Table 6 are consistent with households—-whatever their financing mechanism—-having to reduce future expenditures per member to pay for funerals. These findings are qualitatively similar to those of other studies reviewed in Naidu and Harris (2005).

\section{Problems in the household}

Each adult was asked questions about whether he or she was currently experiencing certain problems. Specifically, the question was asked "Is __ a problem for you right now?" We present the association between reports of having problems and death in the household in Table 7, where all regressions control for age, sex, years of education and nationality. We find that reports of "not having enough money" and "unemployment of family members" are positively, but insignificantly, associated with recent death. We find a significant association between death and 
reports of "not having enough food," "quarrels in the household" and "safety in the neighborhood." All are approximately five percentage points higher with each death of a member aged 6 or older. For 'food' and 'quarrels,' the association between death in the household and these problems can be explained by the lower socioeconomic status of households in which someone died: when a control for expenditure per member is added to each regression, the associations between food and death, and between quarrels and death, become smaller and insignificant.

\section{Investments in children}

The household module asked whether each member aged 5 to 25 was enrolled in school. We use this as a measure of current investments made in children. (We chose not to use educational attainment, because it may reflect school going during the period when the deceased was in need of care.) All regressions include controls for sex, age, age squared, the number of assets the household owns, and the log expenditure per member.

The first two columns of Table 8 present OLS regression results on the association between enrollment and the number of deaths of members by age group (18 and above, 6 to 17, and age 5 and younger). The last three columns present results on the number of deaths of members aged 6 or older. Beginning with results by age group, we find each adult death reduces the probability of enrollment by 4 percentage points, and the death of a 6 to 17 year old reduces the probability by 5 percentage points (although the latter is just shy of being statistically significant). An F-test shows that the difference in the effect of an adult death and that of a 6 to 17 year old are not statistically different $(F$-test $=0.08, p$-value $=0.772)$. Results in column 3 , where all 
deaths above age 5 are combined, show a similar result. Results in columns 1 and 3 are changed by the inclusion of controls for the amount of money spent by the household on the most recent funeral in the past 5 years. (This is zero if the household did not experience a death.) $)^{5}$ Adding the household's expenditure on the funeral and that expenditure squared, the impact of the number of deaths in past 5 years becomes statistically insignificant, whether these deaths are expressed by age category (column 2), or as the number of deaths above the age of 5 (column 5). The household's funeral spending variables are jointly significantly different from zero, whether deaths are expressed by age category $(F$-test $=3.27, p$-value $=0.038)$ or as deaths above the age of $5(F$-test $=2.76, p$-value $=0.064)$. The household's funeral spending variables suggest that each 1000 Rand that the household puts toward the funeral reduces the probability that a member of school going age will be enrolled by approximately 3 percentage points.

\section{Depression and anxiety}

Table 9 presents results on adults reporting symptoms of depression, using questions from an abbreviated CES-D depression scale that asked how often the respondent felt the following

- I felt I could not stop feeling miserable, even with help from my family and friends.

- I felt depressed.

- I felt sad.

- I cried a lot.

- I did not feel like eating. My appetite was poor.

- I felt everything I did was an effort.

- My sleep was restless.

- I could not get 'going.'

\footnotetext{
${ }^{5}$ Results on the impact of household funeral spending are very similar if we restrict the sample to only households that experienced a death in the past five years.
} 
Respondents were asked to report whether, in the last week, they felt these symptoms hardly ever, some of the time, or most of the time. Table 9 presents mean responses for these indicators in square brackets for each depression symptom. Approximately a third of all respondents report having felt miserable, depressed, sad, and having had restless sleep. A quarter report having a poor appetite and an inability to get going. We regress these indicators on age, sex, nationality, years of education, and the number of deaths in the household in the past five years. Women are significantly more likely to report many of these symptoms. Controlling for age, sex and nationality, education appears to be protective against depression. The number of deaths in the household is significantly associated with reports of feeling miserable, feeling depressed, crying a lot, having restless sleep, and reporting an inability to get going.

We aggregate the eight indicators together into an index, and regress that index on the number of deaths in the household of members aged 6 or older, in the first set of columns of Table $10 .{ }^{6}$ We find each death increases the depression index by a quarter of a point, on average. In results estimated but not reported in Table 10, we find that women report a significantly larger number of symptoms, all else held constant. We find education, household asset holdings, and expenditure per member negatively and significantly associated with depression.

In column 2, we restrict the sample to respondents for whom household spending on the funeral is not missing, to make sure the results are not driven by a change is sample composition, and in column 3 we add to this regression the amount of money that household members contributed to the most recent funeral, and that amount squared. We find the depression index increases with the amount spent on the funeral through a spending level of 7200 Rand - well

\footnotetext{
${ }^{6}$ Results are qualitatively similar if we score a report of 'most' of the time as a 2, and 'some' of the time as a ' 1 ' before aggregating the responses into an index.
} 
beyond the $95^{\text {th }}$ percentile of household spending on funerals. Moreover, the inclusion of the household's financial contribution to the funeral reduces the impact of deaths from 0.20 to -0.02 , and leaves it insignificantly different from zero. ${ }^{7}$ Coefficients on several other factors associated with depression (sex, education, assets, expenditure per member) are largely unchanged. (These results were estimated but are not reported in Table 10.)

The last three columns in Table 10 investigate the association between death in the household and reports of anxiety. Specifically, we asked respondents whether "during the past 12 months, did [they] ever have a period lasting one month or longer when most of the time [they] felt worried, tense or anxious." On average, 39 percent of respondents reported that they had. Deaths above age 5 are associated with a 5.5 percentage point increase in the probability of reporting a period of anxiety lasting a month or longer. However, including controls for the household's financial contribution to the most recent funeral, which is significantly associated with reports of anxiety, reduces the coefficient on the death variable to 0.001 and leaves it insignificantly different from zero.

\section{Discussion}

Results in Section 4 suggest that death in the household and household spending on funerals leave household members vulnerable: spending in their households is significantly lower following the funeral, relative to other households; children in households that experienced a death are significantly less likely to be enrolled in school; and adults are significantly more likely to report problems in the household, symptoms of depression, and periods of anxiety.

\footnotetext{
${ }^{7}$ Results on the impact of household funeral spending on depression and anxiety are very similar if we restrict the sample to only households that experienced a death in the past five years.
} 
Children's lower rates of enrollment and adults' reports of depression and anxiety following the death of a member aged 6 or older can be 'explained' by the household's financial contribution to the funeral. The larger the contribution, the less likely it is that children are enrolled in school, and the more likely it is that adults are depressed and anxious. There are, however, alternative explanations for these findings.

We did not observe households prior to the deaths reported in 2004, so we do not know what was true in households before a member passed away. Perhaps spending in these households was always lower than in other households. Children in these households may always have been less likely to be enrolled in school, and adults in these households always more prone to depression and anxiety.

To explore whether households that experienced a death are different from other households in observable ways, we looked in the data for (relatively stable) markers of household socioeconomic status (SES). At the household level, we looked at the association between death in the households and the number of assets the household owned; maximum education of any member; whether the household has access to any kind of toilet facility or latrine; and whether the household lived in a formal dwelling. We present results on these measures of SES in Table 11, where the first four regressions are run at the household level. We find no association between the death of members aged 6 or older and assets holdings, maximum education of a member, or an indicator that the household lived in a formal dwelling. Households that experienced a death might have been asset-poor before the death or may have sold off assets to pay for the funeral, but 
we find no evidence to support either of these ideas. ${ }^{8}$ To the extent we find any significant relationships between deaths and markers of SES, we find that the deaths of infants and children under the age of 6 are significantly associated with larger asset holdings, and greater education of the most educated member in the household. In addition, deaths above the age of 5 are associated with an increased probability of reporting access to any type of toilet facility. Again, these do not strengthen the case that households that had deaths were poorer prior to the death, and we are only picking up that fact in our current data. ${ }^{9}$

We also regress the educational attainment of all adults in the household aged 21 or higher on deaths in the household, with controls for nationality, sex and age. These results, in the last column of Table 11, are also consistent with households that experienced a death being much like other households in the demographic surveillance area.

There are other possible explanations for our findings. For example, the size of the funeral might be larger, the higher the status of the person who died. The loss of a high status member might lead to depression and anxiety among adults left behind. Although we can't rule this out, we can report that household spending on funerals, for those who died above the age of 5, does not correlate with the age of the person who died, or whether the deceased was the head of household, or whether the deceased's financial contribution to the household was important when he or she was healthy. Funeral spending is significantly correlated with the education of the deceased, but only marginally so. So, while this is a possible explanation, we find little evidence

\footnotetext{
${ }^{8}$ In field work in Zululand we rarely observed households selling assets to pay funeral expenses (Case et al. 2008). This is consistent with findings of Roth (1999), who argues that this is largely because the time between the sale of the asset and the receipt of cash is too long for households who need immediate cash to pay for funeral-related items.

${ }^{9}$ Having a better educated member may be correlated with the age structure of the household. The lack of association between death in the household and maximum education of a member continues to be observed in regressions that also control for the age structure of the household.
} 
to support it. (That said, we have made very little progress in understanding the determinants of funeral spending in the field site. If we were able to identify why some funerals were larger than others in the Agincourt Demographic Surveillance Area, we might be in a better position to evaluate the argument that the funeral is a marker for status, and it is the loss of a high status member that leads to future misfortune in the household.)

\section{Conclusion}

A household that experiences the death of a member is at risk for poorer outcomes on a number of dimensions following the funeral, and the risk appears to be greater, the more the household spent to bury their dead. The South African Council of Churches has called repeatedly for "appropriate and affordable" funerals. (See, for example, http://www.sacc.org.za/docs/AnRept05.pdf .) Our results suggest that reining in the size of funerals may improve households' long run prospects. 


\section{References}

Case, Anne, Anu Garrib, Alicia Menendez and Analia Olgiati. 2008. "Paying the piper: the high cost of funerals in South Africa." NBER Working Paper 14456.

Case, Anne and Alicia Menendez. 2007. "Does money empower the elderly? Evidence from the Agincourt Demographic Surveillance Area." Scandinavian Journal of Public Health. 35(3): 157164.

Duflo, Esther, Michael Kremer and Jonathan Robinson. 2008. "How high are rates of return to fertilizer? Evidence from field experiments in Kenya." American Economic Review: Papers and Proceedings 98(2):482-488.

Kahn, Kathleen, Michel L. Garenne, Mark A. Collinson, and Stephen M. Tollman. 2007a. "Mortality trends in a new South Africa: Hard to make a fresh start 1." Scandinavian Journal of Public Health 35 (S69): 26-34.

Kahn K, SM Tollman, MA Collinson, SJ Clark, R Twine, BD Clark, M Shabangu, FX GómezOlivé, O Mokoena, ML Garenne. 2007b. "Research into health, population and social transitions in rural South Africa: data and methods of the Agincourt Health and Demographic Surveillance System." Scandinavian Journal of Public Health Suppl. 69:8-20.

Naidu, Veni and Geoff Harris. 2005. "The impact of HIV/AIDS morbidity and mortality on households - a review of household studies." South African Journal of Economics 73: 533-44.

Roth, Jimmy. 1999. "Informal micro-finance schemes: The case of funeral insurance in South Africa." Social Finance Unit Working Paper 22, International Labour Office, International Labour Organization, Geneva. 


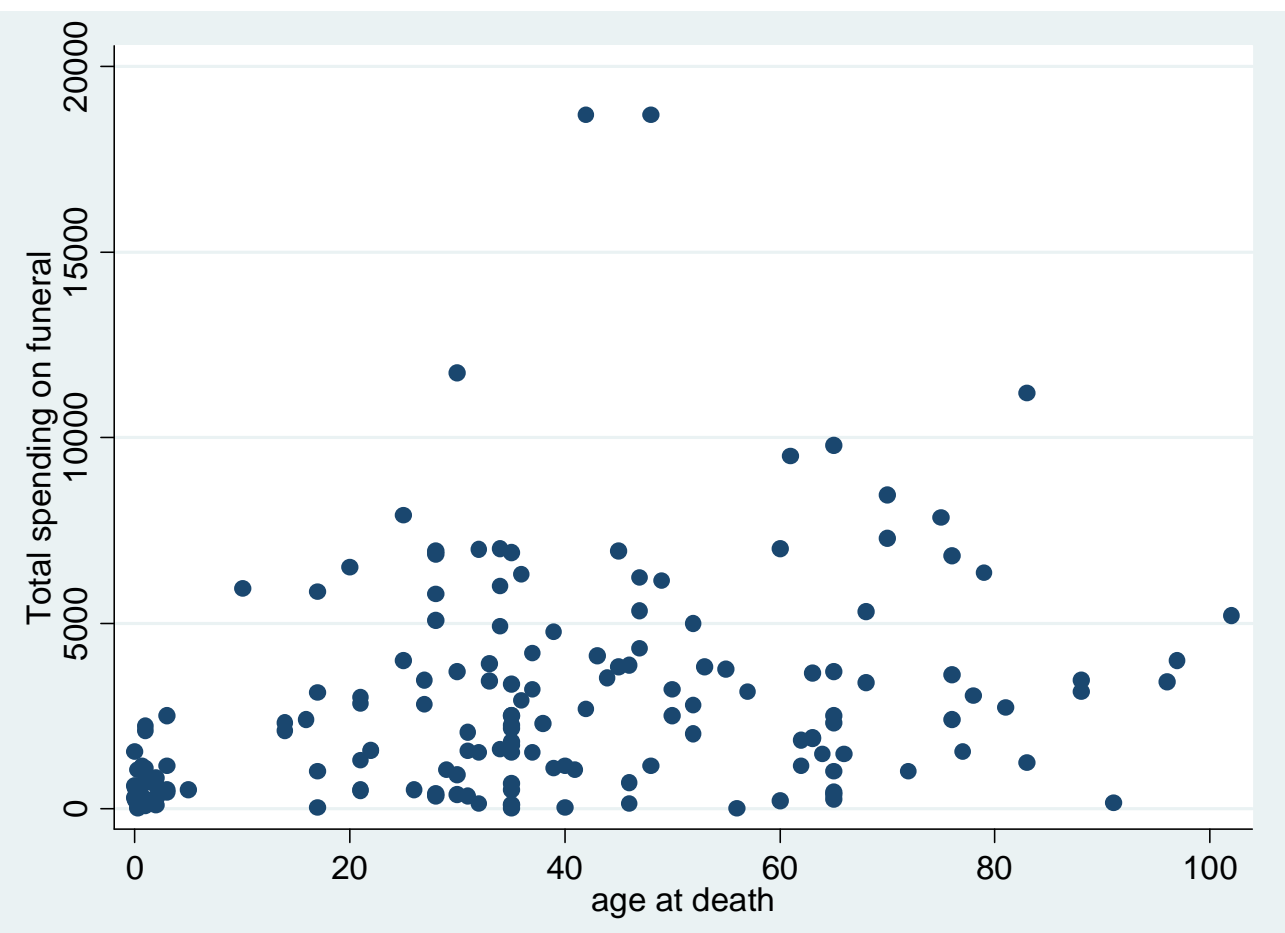

Figure 1. Total spending on funerals by age of death

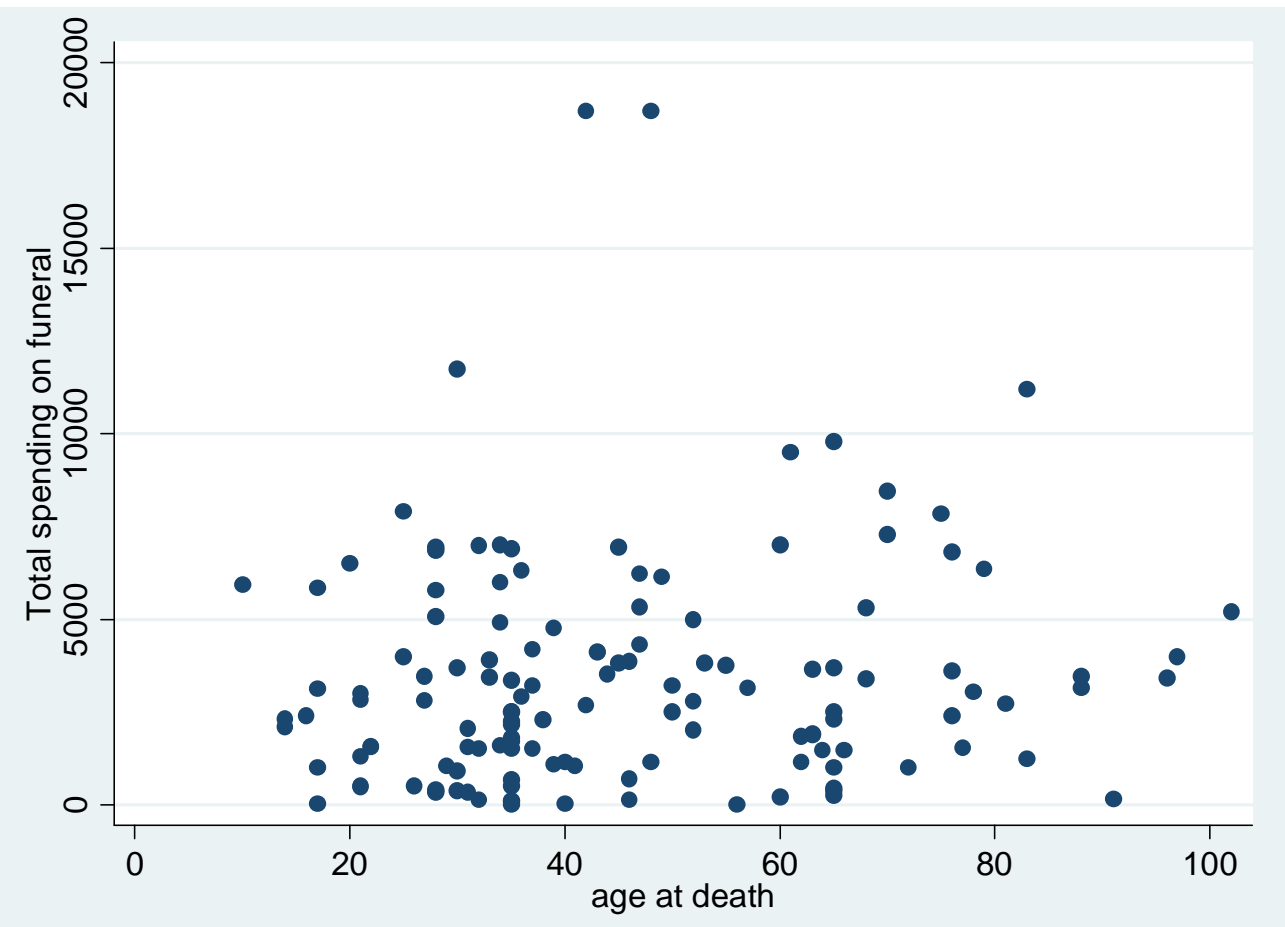

Figure 2. Total spending on funerals for members above age 5 
Table 1. Summary statistics on the households drawn into the sample

\begin{tabular}{lcccc}
\hline \hline & All households & $\begin{array}{c}\text { South African } \\
\text { households }\end{array}$ & $\begin{array}{c}\text { Mozambican } \\
\text { households }\end{array}$ \\
\cline { 2 - 4 } Household size & 6.18 & 5.79 & $6.75^{* * *}$ \\
Number of members aged 0 to 5 & 0.76 & 0.64 & $0.93^{* * *}$ \\
Number of members aged 6 to 17 & 2.06 & 1.90 & $2.30^{* *}$ \\
Number of members aged 18 or older & 3.29 & 3.21 & 3.40 \\
Percent female & 0.52 & 0.52 & 0.52 \\
Total monthly expenditure per member & 161 & 199 & $103^{* * *}$ \\
Total monthly expenditure & 782 & 896 & $611^{* * *}$ \\
Number of assets owned & 5.94 & 6.06 & $3.76^{* * *}$ \\
Number of deaths in past 5 years & 0.49 & 0.46 & 0.54 \\
Number of deaths for members aged 0-5 & 0.11 & 0.07 & $0.15^{* *}$ \\
Number of deaths for members aged 6-17 & 0.03 & 0.03 & 0.04 \\
Number of deaths for members aged 18+ & 0.36 & 0.36 & 283 & 0.36 \\
Number of households & 473 & 0.36 \\
\hline \hline
\end{tabular}

Notes. Sample means presented. Expenditures are reported in Rands. Asterisks in column 3 denote that the difference between South African households and Mozambican households is significant at the 10 percent $(*), 5$ percent $(* *)$ or one percent $(* * *)$ level.

Monthly expenditure is the sum of household spending on mealie meal, bread, milk, cold drinks, sweets, fruit and vegetables, meat, chicken and fish, groceries, rent or bond payment, electricity, rates, fuel, telephone, cell phone, hire purchase, and children's school uniforms, books and fees. 
Table 2. Summary statistics on the deceased

\begin{tabular}{|c|c|c|c|c|c|}
\hline & All & $\begin{array}{l}\text { SA } \\
\text { All }\end{array}$ & $\begin{array}{l}\text { MZ } \\
\text { All }\end{array}$ & $\begin{array}{c}\text { SA } \\
\text { (18 and } \\
\text { older })\end{array}$ & $\begin{array}{c}\text { MZ } \\
\text { (18 and } \\
\text { older) }\end{array}$ \\
\hline Female & 0.428 & 0.421 & 0.438 & 0.451 & 0.483 \\
\hline Age at death & 37.1 & 42.1 & $30.1 * * *$ & 51.3 & $42.3 * * *$ \\
\hline Indicator: pension aged at death & 0.212 & 0.274 & $0.125 * *$ & 0.341 & $0.182 * *$ \\
\hline Years of education & 2.36 & 2.95 & $1.61 * *$ & 3.51 & $2.18^{*}$ \\
\hline Financial contribution was important when healthy & 0.490 & 0.526 & 0.438 & 0.648 & 0.636 \\
\hline Deceased was the household head & 0.428 & 0.474 & 0.363 & 0.582 & 0.527 \\
\hline Number of observations & 194 & 114 & 80 & 91 & 55 \\
\hline
\end{tabular}

Notes. Sample means presented. Asterisks in column 3 denote that the difference between South Africans (SA) in column 2 and Mozambicans (MZ) in column 3 is significant at the 10 percent $(*), 5$ percent $(* *)$ or one percent $(* * *)$ level. Asterisks in column 5 compare results between South Africans in column 4 and Mozambicans in column 5. 
Table 3. Purchases for the most recent funeral

\begin{tabular}{|c|c|c|c|}
\hline & $\begin{array}{c}\text { Fraction reporting } \\
\text { expenditure on } \\
\text { this category }\end{array}$ & $\begin{array}{l}\text { Amount spent, } \\
\text { conditional on } \\
\text { reporting positive } \\
\text { expenditure }\end{array}$ & $\begin{array}{l}\text { Amount spent, } \\
\text { unconditional on } \\
\text { reporting positive } \\
\text { expenditure }\end{array}$ \\
\hline Coffin & 0.65 & 2221 & 1392 \\
\hline Meat & 0.85 & 1099 & 924 \\
\hline Groceries & 0.76 & 693 & 512 \\
\hline Cemetery costs & 0.17 & 343 & 50 \\
\hline Clothing & 0.58 & 188 & 105 \\
\hline Flowers & 0.22 & 112 & 21 \\
\hline Transport & 0.30 & 205 & 47 \\
\hline Food for prayer service & 0.61 & 190 & 100 \\
\hline Other & 0.16 & 337 & 52 \\
\hline Total spending on funeral & -- & -- & $2877(n=165)$ \\
\hline Total, South African household & -- & -- & $3710(n=99)$ \\
\hline Total, Mozambican household & -- & -- & $1629(n=66)$ \\
\hline $\begin{array}{l}\text { Total, knowledgeable household } \\
\text { member }\end{array}$ & -- & -- & $3195(n=140)$ \\
\hline
\end{tabular}

Notes. Sample means presented. Expenditures are reported in Rands. The sample used in the final row is restricted to deaths for which the knowledgeable household member knows the expenditure for meat, or reports that no meat was purchased. 
Table 4. Contributions for the most recent funeral

\begin{tabular}{|c|c|c|c|}
\hline & $\begin{array}{l}\text { Percent of group } \\
\text { reported to have } \\
\text { contributed to the } \\
\text { most recent } \\
\text { funeral }\end{array}$ & $\begin{array}{l}\text { Amount } \\
\text { contributed, } \\
\text { conditional on } \\
\text { reporting positive } \\
\text { contribution }\end{array}$ & $\begin{array}{l}\text { Amount } \\
\text { contributed, } \\
\text { unconditional on } \\
\text { reporting positive } \\
\text { contribution }\end{array}$ \\
\hline Household members & 0.81 & 2478 & 1819 \\
\hline Other family not in the household & 0.73 & 1358 & 882 \\
\hline Community & 0.72 & 344 & 209 \\
\hline Church & 0.53 & 282 & 121 \\
\hline Employer & 0.12 & 2889 & 220 \\
\hline Other & 0.07 & 1165 & 61 \\
\hline Total spending on funeral & -- & -- & $3182(\mathrm{n}=153)$ \\
\hline Total, South African household & -- & -- & $4225(\mathrm{n}=93)$ \\
\hline Total, Mozambican household & -- & -- & $1564(n=60)$ \\
\hline
\end{tabular}

Notes. Sample means presented. Contributions are reported in Rands. 
Table 5. Burial society and funeral policy contributions

\begin{tabular}{lccc}
\hline \hline & Fraction reporting & $\begin{array}{c}\text { Conditional on } \\
\text { reporting money, } \\
\text { amount } \\
\text { transferred }\end{array}$ \\
\cline { 2 - 3 } $\begin{array}{l}\text { Indicator: deceased covered by a } \\
\text { funeral policy or burial society }\end{array}$ & 0.36 & -- \\
$\begin{array}{l}\text { Indicator: policy paid money } \\
\text { Indicator: policy contributed a coffin }\end{array}$ & 0.26 & $\begin{array}{c}\text { mean }=4750 \\
\text { median }=2250\end{array}$ \\
$\begin{array}{l}\text { Indicator: policy contributed food } \\
\begin{array}{l}\text { Indicator: policy contributed } \\
\text { transport }\end{array}\end{array}$ & 0.12 & -- \\
\hline \hline
\end{tabular}

Notes. Sample means presented. The number of observations is 194 for the indicator of having a policy; 193 for indicators that a coffin, food or transport were part of the policy; and 192 for reports of whether money was part of the policy. 
Table 6. Household deaths in the past 5 years and $\log ($ expenditure per member)

Dependent Variable $=\log ($ monthly expenditure per member on household goods)

\begin{tabular}{|c|c|c|c|c|c|c|}
\hline & (1) & (2) & (3) & (4) & (5) & (6) \\
\hline $\begin{array}{l}\text { Number of deaths ages } 18 \text { or older } \\
\text { in the past } 5 \text { years }\end{array}$ & $\begin{array}{c}-0.222 * * * \\
\quad(0.066)\end{array}$ & --- & -- & -- & -- & -- \\
\hline $\begin{array}{l}\text { Number of deaths ages } 6-17 \text { in the } \\
\text { past } 5 \text { years }\end{array}$ & $\begin{array}{l}-0.177 \\
(0.189)\end{array}$ & -- & -- & -- & -- & -- \\
\hline $\begin{array}{l}\text { Number of deaths ages } 0-5 \text { in the } \\
\text { past } 5 \text { years }\end{array}$ & $\begin{array}{l}-0.022 \\
(0.114)\end{array}$ & -- & -- & -- & -- & -- \\
\hline $\begin{array}{l}\text { Number of deaths ages } 6 \text { or older } \\
\text { in the past } 5 \text { years }\end{array}$ & -- & $\begin{array}{c}-0.216^{* * *} \\
(0.063)\end{array}$ & -- & $\begin{array}{c}-0.159^{*} \\
(0.082)\end{array}$ & $\begin{array}{c}-0.187 * * \\
(0.085)\end{array}$ & $\begin{array}{c}-0.278 * * * \\
(0.090)\end{array}$ \\
\hline $\begin{array}{l}\text { Any deaths ages } 6 \text { or older in the } \\
\text { past } 5 \text { years }\end{array}$ & -- & -- & $\begin{array}{c}-0.197 * * \\
(0.090)\end{array}$ & -- & -- & -- \\
\hline $\begin{array}{l}\text { Deceased was of pension age } \\
\text { (latest death) }\end{array}$ & -- & -- & $\begin{array}{c}0.015 \\
(0.150)\end{array}$ & -- & -- & -- \\
\hline $\begin{array}{l}\text { Deceased's income was financially } \\
\text { important (latest death) }\end{array}$ & -- & -- & -- & $\begin{array}{l}-0.134 \\
(0.124)\end{array}$ & -- & -- \\
\hline $\begin{array}{l}\text { Number of deaths ages } 6 \text { or older } \\
\text { interacted with Mozambican }\end{array}$ & -- & -- & -- & -- & $\begin{array}{l}-0.065 \\
(0.126)\end{array}$ & -- \\
\hline $\begin{array}{l}\text { Indicator: most recent death was } \\
\text { 2002-2004 }\end{array}$ & -- & -- & -- & -- & -- & $\begin{array}{c}0.109 \\
(0.114)\end{array}$ \\
\hline $\begin{array}{l}\text { Indicator: household is } \\
\text { Mozambican }\end{array}$ & $\begin{array}{c}-0.582 * * * \\
(0.077)\end{array}$ & $\begin{array}{c}-0.584 * * * \\
(0.077)\end{array}$ & $\begin{array}{c}-0.589 * * * \\
(0.078)\end{array}$ & $\begin{array}{c}-0.588 * * * \\
(0.077)\end{array}$ & $\begin{array}{c}-0.559 * * * \\
(0.091)\end{array}$ & $\begin{array}{c}-0.586 * * * \\
(0.077)\end{array}$ \\
\hline
\end{tabular}

Notes. OLS regressions coefficients are presented, with standard errors in parentheses. Asterisks note that the coefficient is significant at the 10 percent $(*), 5$ percent $(* *)$ or one percent $(* * *)$ level. Regressions are run at the household level for 467 households who answered questions on household expenditures. All regressions include an index for the number of spending categories for which the knowledgeable household member knows something was spent, but does not know the amount. The mean of the dependent variable is 4.729 . 
Table 7. Household deaths in the past 5 years and reports of problems currently facing respondents

\begin{tabular}{|c|c|c|c|c|c|c|c|c|c|c|}
\hline \multirow[b]{3}{*}{$\begin{array}{l}\text { Number of deaths ages } 6 \text { or older } \\
\text { in the past } 5 \text { years }\end{array}$} & \multicolumn{10}{|c|}{ Dependent variable: } \\
\hline & \multicolumn{2}{|c|}{$\begin{array}{c}\text { Not having enough } \\
\text { money } \\
{[0.791]}\end{array}$} & \multicolumn{2}{|c|}{$\begin{array}{c}\text { Not having enough } \\
\text { food } \\
{[0.697]}\end{array}$} & \multicolumn{2}{|c|}{$\begin{array}{c}\text { Unemployment of } \\
\text { family members } \\
{[0.730]}\end{array}$} & \multicolumn{2}{|c|}{$\begin{array}{c}\text { Quarrels in the } \\
\text { household } \\
{[0.287]}\end{array}$} & \multicolumn{2}{|c|}{$\begin{array}{c}\text { Safety in the } \\
\text { neighborhood } \\
{[0.249]}\end{array}$} \\
\hline & $\begin{array}{c}0.021 \\
(0.018)\end{array}$ & $\begin{array}{c}0.010 \\
(0.018)\end{array}$ & $\begin{array}{c}0.051 * * \\
(0.021)\end{array}$ & $\begin{array}{c}0.032 \\
(0020)\end{array}$ & $\begin{array}{c}0.029 \\
(0.020)\end{array}$ & $\begin{array}{c}0.010 \\
(0.019)\end{array}$ & $\begin{array}{l}0.038 * \\
(0.020)\end{array}$ & $\begin{array}{c}0.029 \\
(0.021)\end{array}$ & $\begin{array}{c}0.045^{* *} \\
(0.020)\end{array}$ & $\begin{array}{c}0.039 * \\
(0.20)\end{array}$ \\
\hline Log expenditure per member & -- & $\begin{array}{c}- \\
0.097 * * * \\
(0.016)\end{array}$ & -- & $\begin{array}{c}- \\
0.153 * * * \\
(0.0180\end{array}$ & -- & $\begin{array}{c}- \\
0.152 * * * \\
(0.016)\end{array}$ & -- & $\begin{array}{c}- \\
0.064 * * * \\
(0.018)\end{array}$ & -- & $\begin{array}{c}-0.039 * * \\
(0.017)\end{array}$ \\
\hline Number of observations & 1240 & 1231 & 1239 & 1230 & 1239 & 1230 & 1239 & 1230 & 1239 & 1230 \\
\hline
\end{tabular}

Notes. Standard errors are presented in parentheses. The sample is restricted to adults ages 18 and older. All regressions include controls for age, sex, years of education, and nationality. 
Table 8. Household deaths in the past 5 years and children's outcomes

Dependent Variable: $=1$ if individual is enrolled, ages 5 to 25 [0.723]

\begin{tabular}{|c|c|c|c|c|c|}
\hline $\begin{array}{l}\text { Number of deaths ages } 18 \text { or older } \\
\text { in the past } 5 \text { years }\end{array}$ & $\begin{array}{c}-0.038^{* *} \\
(0.015)\end{array}$ & $\begin{array}{c}0.011 \\
(0.020)\end{array}$ & -- & -- & -- \\
\hline $\begin{array}{l}\text { Number of deaths ages } 6-17 \text { in the } \\
\text { past } 5 \text { years }\end{array}$ & $\begin{array}{l}-0.048 \\
(0.031)\end{array}$ & $\begin{array}{l}-0.058 \\
(0.036)\end{array}$ & -- & -- & -- \\
\hline $\begin{array}{l}\text { Number of deaths ages } 0-5 \text { in the } \\
\text { past } 5 \text { years }\end{array}$ & $\begin{array}{c}0.010 \\
(0.022)\end{array}$ & $\begin{array}{c}0.024 \\
(0.027)\end{array}$ & -- & -- & -- \\
\hline $\begin{array}{l}\text { Number of deaths ages } 6 \text { or older in } \\
\text { the past } 5 \text { years }\end{array}$ & -- & -- & $\begin{array}{c}-0.040 * * * \\
(0.014)\end{array}$ & $\begin{array}{c}-0.030^{*} \\
(0.015)\end{array}$ & $\begin{array}{l}-0.004 \\
(0.019)\end{array}$ \\
\hline $\begin{array}{l}\text { Amount household members paid } \\
\text { for most recent funeral }(1000 \mathrm{R})\end{array}$ & -- & $\begin{array}{c}-0.027 * * \\
(0.014)\end{array}$ & -- & -- & $\begin{array}{r}-0.025^{*} \\
(0.014)\end{array}$ \\
\hline $\begin{array}{l}\text { Amount household members paid } \\
\text { squared }\end{array}$ & -- & $\begin{array}{c}0.001 \\
(0.001)\end{array}$ & -- & -- & $\begin{array}{c}0.001 \\
(0.001)\end{array}$ \\
\hline $\begin{array}{l}F \text {-test: Joint sig of death variables } \\
(p \text {-value) }\end{array}$ & $\begin{array}{c}3.02 \\
(0.029)\end{array}$ & $\begin{array}{c}1.20 \\
(0.308)\end{array}$ & -- & -- & -- \\
\hline $\begin{array}{l}F \text {-test: Number deaths } 18 \text { plus }= \\
\text { Number deaths } 6-17 \text { (p-value) }\end{array}$ & $\begin{array}{c}0.08 \\
(0.772)\end{array}$ & $\begin{array}{c}3.19 \\
(0.074)\end{array}$ & -- & -- & -- \\
\hline Number of observations & 1533 & 1301 & 1533 & 1301 & 1301 \\
\hline
\end{tabular}

Notes. OLS regression results, with standard errors presented in parentheses. All regressions include controls for sex, age, age squared, number of assets the household owns, log expenditure per member, and nationality. 
Table 9. Household deaths in the past 5 years and markers for depression

\begin{tabular}{|c|c|c|c|c|c|c|c|}
\hline & \multicolumn{7}{|c|}{ Dependent variable: } \\
\hline & $\begin{array}{c}\text { Felt } \\
\text { miserable } \\
{[0.317]}\end{array}$ & $\begin{array}{c}\text { Felt } \\
\text { depressed } \\
{[0.400]}\end{array}$ & $\begin{array}{c}\text { Felt } \\
\text { sad } \\
{[0.361]}\end{array}$ & $\begin{array}{c}\text { Cried } \\
\text { a lot } \\
{[0.106]}\end{array}$ & $\begin{array}{c}\text { Poor } \\
\text { appetite } \\
{[0.288]}\end{array}$ & $\begin{array}{c}\text { Restless } \\
\text { sleep } \\
{[0.417]}\end{array}$ & $\begin{array}{c}\text { Could not } \\
\text { get going } \\
{[0.269]}\end{array}$ \\
\hline $\begin{array}{l}\text { Number of deaths ages } 6 \text { or older } \\
\text { in the past } 5 \text { years }\end{array}$ & $\begin{array}{l}0.035^{*} \\
(0.021)\end{array}$ & $\begin{array}{l}0.036^{*} \\
(0.021)\end{array}$ & $\begin{array}{c}0.007 \\
(0.021)\end{array}$ & $\begin{array}{c}0.041 * * * \\
(0.014)\end{array}$ & $\begin{array}{c}0.027 \\
(0.020)\end{array}$ & $\begin{array}{c}0.044 * * \\
(0.021)\end{array}$ & $\begin{array}{c}0.054^{* * *} \\
(0.019)\end{array}$ \\
\hline Indicator: female & $\begin{array}{c}0.041 \\
(0.027)\end{array}$ & $\begin{array}{c}0.044 \\
(0.028)\end{array}$ & $\begin{array}{c}0.077 * * * \\
(0.028)\end{array}$ & $\begin{array}{c}0.115^{* * *} \\
(0.018)\end{array}$ & $\begin{array}{c}0.076 * * * \\
(0.026)\end{array}$ & $\begin{array}{c}0.082 * * * \\
(0.028)\end{array}$ & $\begin{array}{c}0.066^{* * *} \\
(0.025)\end{array}$ \\
\hline Years of education & $\begin{array}{c}-0.015 * * * \\
(0.005)\end{array}$ & $\begin{array}{c}-0.024 * * * \\
(0.005)\end{array}$ & $\begin{array}{c}-0.020 * * * \\
(0.005)\end{array}$ & $\begin{array}{c}-0.008^{* *} \\
(0.003)\end{array}$ & $\begin{array}{c}-0.017 * * * \\
(0.005)\end{array}$ & $\begin{array}{c}-0.019 * * * \\
(0.005)\end{array}$ & $\begin{array}{c}-0.008^{*} \\
(0.004)\end{array}$ \\
\hline Number of observations & 1236 & 1235 & 1235 & 1234 & 1235 & 1235 & 1236 \\
\hline
\end{tabular}

Notes. OLS regression coefficients reported, with standard errors presented in parentheses. The sample is restricted to adults ages 18 and older. All regressions also include controls for age and nationality. 
Table 10. Household deaths in the past 5 years, and reports of depression and anxiety

\begin{tabular}{|c|c|c|c|c|c|c|}
\hline \multirow[b]{3}{*}{$\begin{array}{l}\text { Number of deaths ages } 6 \text { or older } \\
\text { in the past five years }\end{array}$} & \multicolumn{6}{|c|}{ Dependent variable: } \\
\hline & \multicolumn{3}{|c|}{$\begin{array}{c}\text { Depression index } \\
{[2.46]}\end{array}$} & \multicolumn{3}{|c|}{$\begin{array}{c}=1 \text { if reported a month of worry } \\
{[0.390]}\end{array}$} \\
\hline & $\begin{array}{c}0.262 * * * \\
(0.107)\end{array}$ & $\begin{array}{l}0.202 * \\
(0.122)\end{array}$ & $\begin{array}{l}-0.022 \\
(0.152)\end{array}$ & $\begin{array}{c}0.055^{* *} \\
(0.022)\end{array}$ & $\begin{array}{c}0.065^{* * *} * \\
(0.025)\end{array}$ & $\begin{array}{c}0.001 \\
(0.031)\end{array}$ \\
\hline $\begin{array}{l}\text { Amount household members paid } \\
\text { for most recent funeral (1000 R) }\end{array}$ & -- & -- & $\begin{array}{l}0.245 * * * \\
(0.100)\end{array}$ & -- & -- & $\begin{array}{c}0.076 * * * \\
(0.020)\end{array}$ \\
\hline $\begin{array}{l}\text { Amount household members paid } \\
\text { squared }\end{array}$ & -- & -- & $\begin{array}{c}-0.017 * \\
(0.009)\end{array}$ & -- & -- & $\begin{array}{c}-0.006^{* * *} \\
(0.002)\end{array}$ \\
\hline Number of observations & 1225 & 1079 & 1079 & 1226 & 1079 & 1079 \\
\hline
\end{tabular}

Notes. OLS regression coefficients reported, with standard errors presented in parentheses. The sample is restricted to adults ages 18 and older. The depression index is the sum of self-reports that some or most of the time in the past week the respondent felt miserable; felt depressed; felt sad; cried a lot; did not feel like eating; felt everything was an effort; had trouble sleeping; and could not get 'going.' Also included in each regression are controls for age, age squared, sex, education, number of assets owned, log expenditure per member, and nationality. 
Table 11. Correlates of death in the households in the past 5 years

\begin{tabular}{|c|c|c|c|c|c|}
\hline & & & Dependent variable: & & \\
\hline & $\begin{array}{c}\text { Number of assets } \\
\text { [5.14] }\end{array}$ & $\begin{array}{l}\text { Maximum } \\
\text { education of a } \\
\text { member } \\
\text { [7.42] }\end{array}$ & $\begin{array}{c}\text { Access to any type } \\
\text { of toilet or latrine } \\
{[0.793]}\end{array}$ & $\begin{array}{c}\text { Formal dwelling } \\
\qquad[0.867]\end{array}$ & $\begin{array}{c}\text { Education of } \\
\text { adults }(21+) \\
{[4.85]}\end{array}$ \\
\hline $\begin{array}{l}\text { Number of deaths ages } 6 \text { or older } \\
\text { in the past } 5 \text { years }\end{array}$ & $\begin{array}{l}-0.021 \\
(0.201)\end{array}$ & $\begin{array}{c}0.165 \\
(0.243)\end{array}$ & $\begin{array}{c}0.073 * * \\
(0.029)\end{array}$ & $\begin{array}{c}0.034 \\
(0.025)\end{array}$ & $\begin{array}{c}0.036 \\
(0.130)\end{array}$ \\
\hline Number of deaths ages 0 to 5 & $\begin{array}{c}0.738^{* *} \\
(0.366)\end{array}$ & $\begin{array}{c}0.934 * * \\
(0.442)\end{array}$ & $\begin{array}{c}0.003 \\
(0.054)\end{array}$ & $\begin{array}{c}0.015 \\
(0.043)\end{array}$ & $\begin{array}{c}0.255 \\
(0.218)\end{array}$ \\
\hline Number of observations & 473 & 472 & 473 & 472 & 1284 \\
\hline
\end{tabular}

Notes. OLS regression coefficients reported, with standard errors presented in parentheses. All regressions also include a control for nationality. The final column also includes controls for age and sex. 